DRYSTONE WALL, AN IMPORTANT ELEMENT OF KARST CULTURAL LANDSCAPE: AN EXAMPLE OF DINARIC KARST

\section{Andrej Kranje}

Karst Research Institute, Titov trg 2, Si-6230 Postojna, slovenia,kranjc@zrc-sazu.si

\section{Abstract}

The technique of drystone construction started in prehistory at Dinaric Karst. There are different types of drystone wall, from simple single file, to dual construction walls with in-between fills of stones, and big heap enclosures of several files of drystone. Shelters of different size can be incorporated in drywalls. The type of drystone wall depends on the quantity of stone that must be removed. Drywall has different functions: a dump of rocks due to "cleaning" the karst surface (up to $1400 \mathrm{~kg}$ of stone $/ \mathrm{m}^{2}$ ), a boundary of property, a factor of channelling (the herds between two walls) or gathering (enclosure, fold), and a defence against wind erosion. Walls are of different ages, from the ancient Antiquity (Greek colonies) to the more recent times. Drystone-walls' construction time varies dramatically from few years to a whole generation's life time. Nowadays drystone walls are so typical and conformable to a great part of Dinaric Karst that they are an essential form of the landscape. Whatever form drystone walls assume, they are so close to nature that they become a part of it, and although created by man they are not alien.

\section{Introduction}

The oldest stone constructions were made by drystone technique. This is not just particular to the karst but to the world at large, from Palaeolithic and Neolithic onwards. An example is the low stone enclosures made by Palaeolithic hunters along the Atlantic coast. They were used for catching fish in the low tide. Similar structures can be found along the Baltic coast. The stone platforms in Finland are also of similar age. Extreme examples are Megalithic structures, tombs and dolmens, of which the Stonehenge is the most obvious. Drywall techniques were used to construct big grave mounds like Newgrange (Ireland) and the stone circles in Northern Europe. They were also used for dwellings like Skara Brae (Orkneys) [1]. Prehistoric fortresses and fortified places were usually built by drystone techniques in rocky landscapes. Many examples of this are from Dinaric Karst too, such as Debela griža near the village of Volčji Grad.

\section{Drystone techniques}

Drystone technique is quite simple - piling up stones in a certain shape. Way of arranging depends also on the material at disposal (the natural form of the stone itself). If the stones are regular they can be piled up similar to bricks. If the stones are of very irregular form, the stones of different dimensions are used. The type of a drystone wall depends on the material at hand and on the techniques used: from simple wall of just one stone above another to a much elaborate structures in a large double-wall structures with metals in-between (Fig. 1).

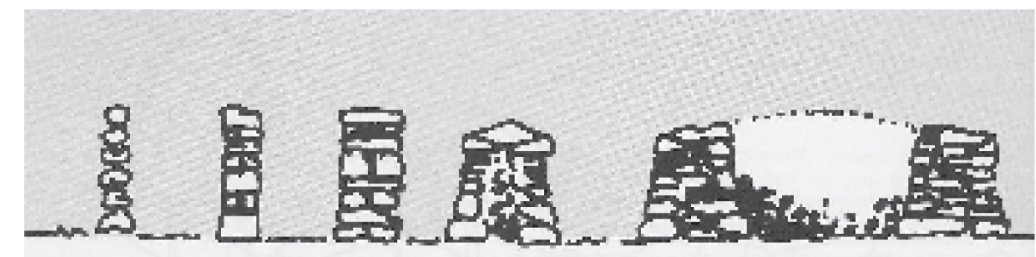

Fig. 1: Cross sections of different types of drywalls [2]. 
The drystone wall can contain additional elements for crossing the wall or to prevent animals from crossing the passage such as: longitudinal or transversal steps, console steps, narrow openings in the wall, larger openings with the "needle" in the middle (to prevent animals from passing), or simple large openings. These elements need either special type of construction (steps) or special type of stone (large boulders for doorposts). There can also be a niche in the wall, sometimes with a stone slab acting as a small roof, or a larder for a loaf of bread and a bottle of wine. This is the first phase of drystone building, serving as a store, shelter or even for living (Barraca in Spain, Cabane in France, and Trullo from Southern Italy) [2], constructed in the same technique as a drystone wall (Fig. 2). of the doline - bigger plot for cultures. Around many villages there are often shallow dolines with relatively large flat bottoms and bare slopes - dolines that were changed by Man. In folk language this types of doline is called "elaborate doline" [3].

\section{Function of a drystone wall}

The most important consequence of drystone wall construction is perhaps the heaping up of the surplus stones. In Dinaric Karst natural karst surface can be used for the grazing of sheep and goats at the best. To get cultivable surfaces, Man had to clean stones away. Dinaric karst, to the middle of the $20^{\text {th }}$ century, people have been removing stones manually, later on this has been done by machines. Removing stones did not

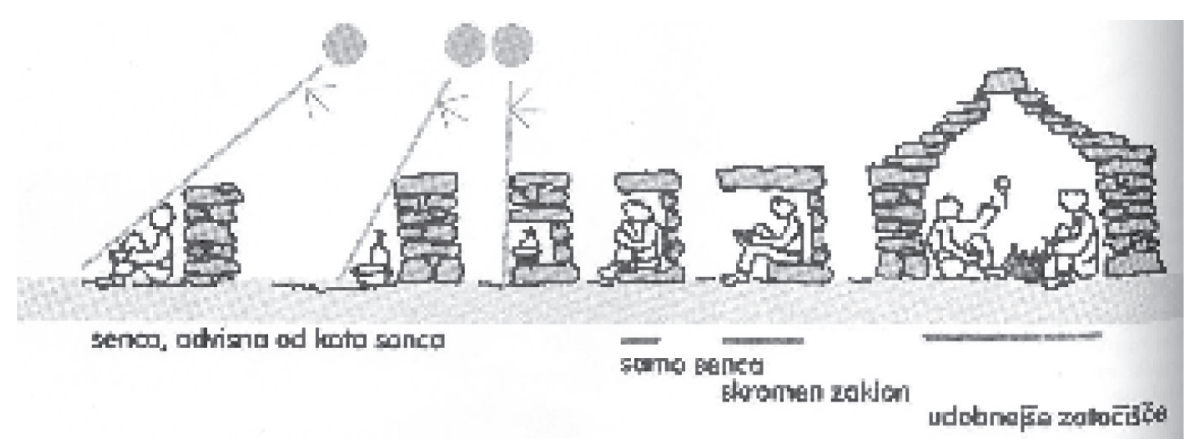

Fig. 2: Evolution from simple drystone wall to drystone cabin [2].

Form and type of a drystone wall depend also on the quantity of stone available. This is how much stone has to be removed and put on the construction to occupy as little as possible of a cultivable surface. The simplest method is to make a heap of stone. If there are more stones, the heap can then be elongated. Even more stones can be put in a drystone wall, by making a dual file wall and, in extreme, rectangle place can enclose a fill of stones.

In Dinaric Karst people used another way to get rid of superfluous stone, just opposite of a drystone wall construction. Man hollowed out the sediment at the bottom of a doline. The pit was filled with stone and covered by sediment. Soil was scraped from the slopes of the doline and from the soil pockets on the nearby surface too. Thus larger flat soil surface was made in the bottom mean just picking them up, but also digging them right out of the ground. It was necessary to dig out stones that were too shallow and might prevent tillage by ploughing. Machine tillage reach deeper. As such, deeper lying stones have to be removed too.

Nowadays on Dinaric Karst there is no more need for new cultivable land due to economic and demographic changes. Often even cultivated land is abandoned and slowly overrun by weed bushes and trees, evolving into forests. If machines are used in some of these places, cultivable land might still be enlarged. This is mainly the case of vineyards. But now the process is just the opposite of what it used to be before. Sediment from the bottom of dolines is excavated by machines and spread on flat surfaces. So former shallow "elaborated dolines" are being changed into funnel shape ones, without 
sediment at their bottoms. And in both cases, shapes of dolines are no longer natural, but rather manufactured by human interference.

The quantity of stone taken up and put into a drystone wall can, in instances, be very big. Here are some examples from Dinaric coast. Around the village of Punat (Krk Island) people removed from $1188-1$ $300 \mathrm{~kg}$ of stone per $\mathrm{m}^{2}$, and at the territory of Velo Polje (Hvar Island) up to $1103 \mathrm{~kg} / \mathrm{m}^{2}$. The research on the Vis Island shows an obvious difference between a flat surface $\left(63-314 \mathrm{~kg} / \mathrm{m}^{2}\right)$ and the slope surface $\left(1430 \mathrm{~kg} / \mathrm{m}^{2}\right)$.

Therefore the quantity of drystone walls is greater, bigger and larger as well as denser is their net. Coming back to the example of the island Krk, in the territory of the village Punat. On the plots of vineyards and olive trees, the cultivated land represents $45 \%$ of the gross size of the place, drystone walls represent 43 $\%$, and bare rocks represent $12 \%$. If we try to apply this data to greater areas, the quantities of picked up stones put into drystone walls are really surprising: from 6,3 $\mathrm{t}$ of stone in flat terrain (around Velo Polje on the island Hvar) to $130 / \mathrm{t}$ around Punat on the island Krk [4]. And we must not forget that all these rocks were picked up, dug out and incorporated into a drystone wall by hand.

Besides being a store place for stone, a drystone wall has other functions too. It can act as boundaries for properties.
It can direct livestock towards pasture or watering places. Special forms were "karst streets" between drystone walls leading flocks during the transhumance travel for long distances. Drystone walls were used for gathering livestock too, and to sort special types of animals (young for example), to gather animals for milking or for securing livestock overnight in (a drystone corral) [5].

A very important function of drystone wall, throughout history, has been protection against wind; the strong cold North-Eastern wind; Burja or Bura (Borealis). Eolian soil erosion, particularly in winter, when there is no vegetation and the land is dry, can be very significant (Fig. 3). This was even more serious in previous times when due to deforestation the share of bare landscape was much greater than nowadays. From the observations of small plots of cultivated land, exposed to strong Burja wind, it was possible to calculate great amounts of soil driven away by the wind [6]. Soon after 1857, when the railroad from Vienna reached Trieste [7], trains were so often stopped by snowdrifts made by Burja that a decision was made to build protection drystone walls. Practically, the whole distance $(40 \mathrm{~km})$ of the railroad which passes through the region Kras (It has given the international term "karst") was enclosed by drystone walls. This construction work was, thus, much cheaper than the alternative which would have required a whole

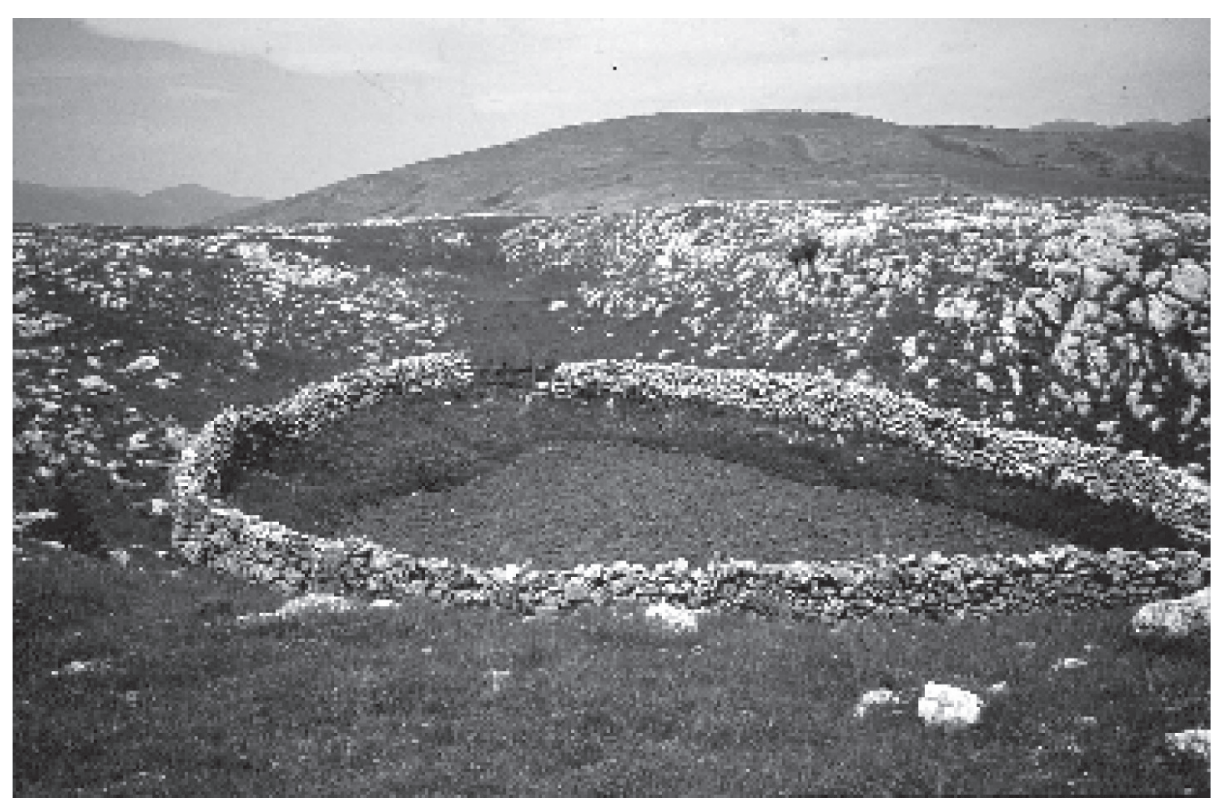

Fig. 3: Bottom of a doline protected by drystone wall. 
army of workers to clean up the railroad every winter.

And at the end, let me say few words about the contemporary function of drystone walls. It can either be an obstacle to modern means of transportation hindering the widening and modernisation of roads or, a stock of stones suitable for immediate use and utility in various beneficial functions. In some regions, one can often see modern machines loading stones of drystone-walls and simultaneously crushing them into construction material. Thus an important or even crucial element of cultural landscape of Dinaric Karst is slowly disappearing away.

\section{Time question}

This can be looked at from two points of view. Firstly, it can be seen in terms of how old are drystone walls in Dinaric Karst, and, secondly, in terms of how much time was needed to construct such walls. It can be said that a man has started to clear the rocky karst surface when he started to till the land, during the Neolithic. There are drystone walls encircling fortified villages from Hallstatt (Older Iron Age) period. The surface inside those walls can relatively be large such as on the plateau of Kras. Such a village Debela Griža covers 3 ha of a good soil without rocks. Part of the surface was not build up, but left open, maybe for a field. This means that the surface has been cleared and stone used for the construction of walls [8].

The island Hvar was colonised by ancient Greeks in the $4^{\text {th }}$ century B.C. There is the basic net of drystone walls from these times. Only the basic one, however, is parcelling out according to the colony. During later phases of construction, the net of drystone walls became more and more dense. So, the majority of them are much younger, the youngest is even from $19^{\text {th }}$ and $20^{\text {th }}$ centuries. There is an open question as to why the first settlers - colonists - did not construct denser net of walls. Did they not need to clear the land because of their manual cultivation methods, or did the stone appear sporadically in their plots due to accelerated soil erosion?

Kornati Islands (Dalmatia) are uninhabited for centuries. In the middle of the $18^{\text {th }}$ century, landlords (noble families from the coast towns) sold the islands to the agrarian communities of neighbouring islands. At that time, there was no drystone wall on Kornati islands. Future buyers, and their followers, worked to border their property by drystone walls in due time. In few years the net of drystone walls criss-crossed the whole of the islands. At the beginning there were drystone walls just to border the land. Later on, they fenced pastures, and finally they began to clear the land to get some plots ready for cultivation of olive- and fig trees, or vines. During the years 1890 to 1910 there were 56 cleared ha [9]. Otherwise the clearing of stones was the family job during winter. Before plots were cleared and drystone walls errected, this work occupied the whole of the winter seasons for several generations.

\section{Conclusion}

Let me finish with the words of a Slovene architect studying in details drystone walls all over the world: "Whatever the form drystone walls assume, they are so close to nature that they become a part of it and although created by human they are not alien.” [2]. On the Dinaric Karst there are regions where one cannot imagine the landscape without drystone walls. It is not just an essential element of the landscape but the landscape itself can be identified by their presence (Fig. 4). It is a pity that a lot of people are not conscious of this fact and look upon drystone walls nowadays as an obstacle worth only getting rid of. Drystone walls are loosing their significance. Man does not maintain or repair them any more, but rather simply leave them to wither away and disapear. 


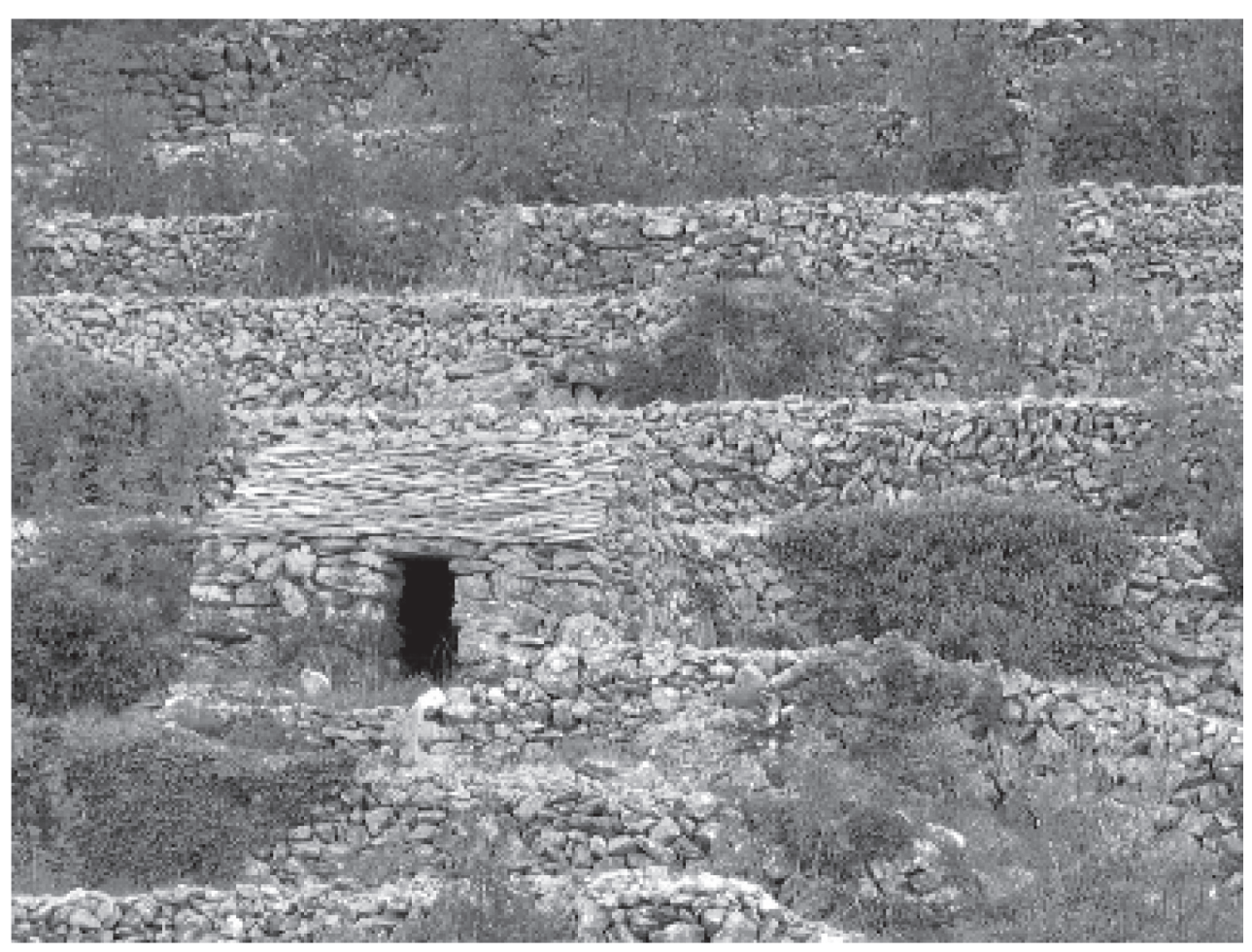

Fig. 4: In some parts of Dinaric Karst landscape itself can be identified by a drystone wall.

\section{References}

1. M. Taviani, in A. Capodiferro (ed.) Wonders of the

World, White Star Publishers, Vercelli, 2004, p.319

2. B. Juvanec, Kamen na kamen, Založba i2, Ljubljana, 2005, p.139

3. I. Gams, Kras v Sloveniji v prostoru in času, Založba ZRC, Ljubljana, 2004, p.515

4. I. Gams, in Karst and Man, International

Geographical Union, Study Group on Man's impact in karst, Ljubljana, 1987, p.76-87

5. B. Aničić and D. Perica, Acta carsologica, 32, 1 (2003), $173-188$
6. J. Wessely, Das Karstgebiet Militär-Kroatiens, Commissions-Verlag der Universitäts-Buchhandlung Albrecht \& Fiedler, Agram, 1876, p. 251

7. J. Orbanić, in R. Gospodarič (ed.) Ljudje in kraji ob Pivki, Kulturna skupnost Postojna, Postojna, 1985, p. 239-243

8. P. Turk, in Enciklopedija Slovenije, Vol. 14, Mladinska knjiga, Ljubljana, 2000, p.348

9. S. Kulušić, Geografski glasnik, 27 (1966), 215-245 